\title{
DIFFERENCES IN LANGUAGE SKILLS FIRST GRADE STUDENTS IN RELATION TO THE LENGTH OF ATTENDING KINDERGARTEN
}

\section{LeilaBegić ${ }^{1, a}$ \\ Mirela Duranovića Karagić Samra ${ }^{\mathrm{b}}$}

Original scientific paper

Faculty of Education and Rehabilitation, University of Tuzla, $B \& H^{a}$

Health center "Maglaj" and Elementary school "Novi Šeher", Novom Šeher, B\&Hb

Received: 10.06 .2016

Accepted: 12.07.2016

\begin{abstract}
Aim of this research was to examine differences in linguistic abilities of first year students in elementary schools depending on time spent in kindergarten. In research, sample of surveyed students consisted of 190 first year students in elementary schools, both genders and ages between 72 and 89 months. The research was conducted in elementary schools on the territory of municipality Maglaj in Bosnia and Herzegovina. Results of this research have shown that during the evaluation of differences in linguistic abilities of first year students in elementary schools depending on time spent in kindergarten, there is statistically significant difference in grammatical variable that describes morphological completion. Children that attended kindergarten more than three school years, showed statistically better results with recognition abilities, understanding and usage of common morphological forms of Bosnian language, compared to children who attended kindergarten only for legally obliging preschool time (minimal 150 hours during one school year). We have to point out that respondents who attended kindergarten more than three school years showed better results in almost every variable that describes linguistic abilities but obtained difference did not appear as statistically significant. Professionals who deal with education and rehabilitation of children in development period should educate and stimulate parents to enroll their children in kindergarten in order to stimulate their speaking - linguistic development and other areas that children are developing in.
\end{abstract}

Keywords: linguistic abilities, first year students, attending kindergarten

\section{INTRODUCTION}

Language is rich, complex and adaptable system; it represents a manner of combining letters, words, signs and sentences in order to express thoughts and understanding other people. With the help of language, people socialize and learn (Apel and Masterson, 2004). Language is expressed through reception and expression, through reading, writing and speech (Brandone,
Salkind, Golinkoff and Hirsh - Pasek, 2006). Linguistic disorders represent disrupted understanding of speech, disrupted usage of speech, writing and/or other systematic symbols. These disorders can involve form of language (phonology, morphology, and syntax), meaning (semantics) and/or function of language in communication (pragmatics) (Owens, 2004).

\section{${ }^{1}$ Correspondence to:}

Leila Begić, Faculty of Education and Rehabilitation, University of Tuzla, Bosnia and Herzegovina Univerzitetska 1, 75000, Tuzla, $\mathrm{B} \& \mathrm{H}$

Phone: +387 (0) 61502350

E-mail: leila.begic@untz.ba 
Many children have difficulties in one or more areas of linguistic development. For example, some children have difficulties with phonology i.e. pronunciation and their speech can be hard to understand. Other children have difficulties with grammar and they are not able to adopt the rules of grammar spontaneously and their language is diagrammatic. Some children have difficulties in using language in order to expressing their needs. It is also important to note that some children have difficulties in multiple linguistic areas (Apel and Masterson, 2004). For most of the children developing language is not a problem. Until the age of five, children with typical development have completed building the system and they have to enhance and integrate adopted skills in order to use language in more complex tasks wich they face on a daily basis (Brandone, Salkind, Golinkoff and Hirsh - Pasek, 2006). Linguistic skills support every human interaction and therefore are a key for success of a child both in school and with peers. Linguistic problems have an effect on reading, writing and communicating abilities (Catts, Fey, Tomblin and Zhang, 2002, according to Brandon, Salkind, Golinkoffand Hirsh - Pasek, 2006). Before school, a child has to accomplish a certain degree of physical, social, mental and motivational - emotional development. Educational process requires a child to be able to perform mental tasks, differentiate similarities and differences in objects and appearances of surrounding world and it has to be capable of self-control and planning of its own actions. Besides aforementioned, a child has to have developed fine motorics, visualmotoric coordination, the correct pronunciation and a certain degree of phoneme hearing. Those are necessary conditions for successful verbal communication and adopting skills of reading and writing (Ivanovskz and Gadasin, 2010). When we observe effects of different variables on a child's development, we have to point out that besides family, one of the most influential things on child's socio - emotional development have peers. Children's interactions with peers in a nursery and kindergarten contribute to social competence, prosocial skills and less aggressive behavior (Bartolotta and Schulman, 2010). One of the most important roles of institutional preschool education is to prepare children for school. That role is important for individual, family and society in general for several reasons. First of all, as most experts of different scientific areas claim, is that most important abilities are being developed during first five years of life. After that period, other abilities can only upgrade on those (Shonkoff and Phillips, 2000, Heckman, 2006, according to Baran,
2013). Better education in preschool institutions influence more intense development of cognitive functions, development of linguistic abilities and development of communicational skills (Burchinal and Sar, 2000, according to Krzewina, 2012). In accordance with aforementioned, we have defined aim of this research that was to examine differences in linguistic abilities of first year students in elementary schools, depending on time spent in kindergarten.

\section{RESEARCH METHODS}

\section{Respondents sample}

In research, sample of surveyed students consisted of 190 first year students in elementary schools, both genders and ages between 72 and 89 months (6 years to 7 years and 5 months old). The research was conducted in elementary schools on territory of municipality of Maglaj in Bosnia and Herzegovina. Research was conducted individually in accordance of propositions of the test.

\section{Variable sample}

Variables used in this research can be divided into two groups:

anamnesis variables and variables for examining linguistic abilities of first grade students in elementary schools.

\section{Anamnesis variables}

1.Students' gender; male and female respondents.

2.Students' age: in months.

3.Duration of attending kindergarten (DAK): obligatory program of preschool education - minimal 150 hours during one school year; attending organized forms of preschool education in duration more than three years.

Variables for examining linguistic abilities of first grade students in elementary schools

1.Differentiation of words descriptive term (DWDT).

2.Phonemic analysis descriptive term (PADT).

3.Phoneme descriptive term (PDT).

4.Pictorial vocabulary descriptive term (PVDT).

5.Relational vocabulary descriptive term (RVDT).

6. Verbose dictionary descriptive term (VDDT).

7.Syntax understanding descriptive term (SUDT).

8.Repetition of sentences descriptive term (RSDT).

9.Morphological completion descriptive term(MCDT). 
The method of conducting research and measuring instrument

The research was conducted in elementary schools on territory of Maglaj municipality in Bosnia and Herzegovina. Permission to conduct the research was given by the parents as well by schools' principals. To examine linguistic abilities of first grade students Test of language development- TOLDP4 was used that has been translated and adjusted to Bosnian language (Newcomer and Hammill, 2008). As a part of examining linguistic abilities, phonemic, semantic and grammar structure of language abilities were examined as well. Test was composed of 9 subtests, where we had 6 main subtests (Pictorial dictionary, Relational dictionary, verbose dictionary, Syntax understanding, Sentences repetition and Morphological completion) and 3 additional subtests (Words differentiation, Phonemic analysis and Phoneme). During examination for 6 main subtest, 190 children were examined - the whole sample. According to propositions of the test, 3 additional subtests are not used for examining children older than 7 years. Therefore, children older than 7 years were not examined with 3 additional subtests that examine abilities of words differentiation, phonemic analysis and phoneme. In other words, in examination of 3 additional subtests participated children from age of 72 to 84 months which is 165 children. Phonologic ability of students is examined with subtests "Words differentiation", "Phonemic analysis" and "Phoneme". Subtest "Words differentiation" is consisted of 28 tasks where children's abilities to differentiate similar words were measured. Subtest "Phonemic analysis" was consisted of 22 tasks and was used to measure ability to separate words into smaller phonemic units. Phonological test "Phoneme" was consisted of 25 tasks and was used to measure child's ability to pronounce letters of Bosnian language. Semantic abilities of students were examined through subtests "Pictorial dictionary" and "Verbose dictionary". Semantic subtest "Pictorial dictionary" with total of 34 tasks shows respondents' understanding of pronounced words in Bosnian language. Semantic subtest "Relational dictionary" with total of 34 tasks shows child's ability to understand and pronounce connection between two stimulatory words. Child should understand the meaning of the word; recognize its semantic category and their connection. Subtest "Verbose dictionary" consists of total 38 tasks that measure child's ability to define the term that examiner pronounces. Abilities in grammatical structure of language were examined through subtests "Syntax understanding", "Sentences repetition" and "Morphological completion". Subtest "Syntax understanding" was consisted of total 30 tasks that evaluated child's ability to understand meaning of sentences. With test "Sentences repetition" with total of 36 tasks we measured child's ability to repeat pronounced sentences. Grammar subtest "Morphological completion" with total of 38 tasks evaluated child's ability to recognize, understand and usage of common morphological forms of Bosnian language. Descriptive terms that relate to level of development of phonological, semantic and grammatical abilities are represented as: 1 - very bad, 2 - bad, 3 - under average, 4 - average, 5 - above average, 6 - excellent and 7 - outstanding.

\section{Statistical data processing}

Data was processed with statistical program SPSS 20.0. Statistical significance was taken into account for $\mathrm{p}<0.05$. In statistical data processing, for each variable, basic statistical parameters were calculated: arithmetic mean, standard deviation, minimal and maximum result and frequencies. For differences in particular variables examination t-test was used.

\section{RESULTS}

From total of 190 students, 107 students were male students $(56.3 \%)$ and 83 students were female students (43.7\%). Observing the variable that describes time spent in kindergarten, from 190 respondents, 176 of them attended legally obligatory education in duration of minimal 150 hours during one school year, while 14 respondents attended preschool education more than three school years. Respondents' age was between 72 and 89 months. In table 1 basic statistical indicator of all variables are shown that describe linguistic abilities of students of first grades. Analyzing phonological ability of total 165 students, results have shown that in variable "Words Differentiation descriptive term", minimal achievement was 1 point and maximal achievement was 6 points with average of 5.31 points, which suits descriptive term excellent abilities. In variable "Phonological analysis descriptive term" results varied between 3 to 5 points, with average of 4.02 points, which indicates that abilities of phonological analysis of students of first grades accord to average abilities. In variable "Phoneme descriptive term" results varied between 1 and 7 points, with average of 4.54 points which accord area of average and above average abilities.

Also, in Table 1 are shown results of variables that describe semantic abilities of 190 students of first grades in elementary schools. 
In variable "Pictorial dictionary descriptive term" results varied between 4 and 7 points with average of 4.55 points, which is between average and above average abilities. Results that describe variable "Relational abilities descriptive term" varied between 1 and 7 points with average of 4.27 points which relates to descriptive term of average abilities. Analyzing variable "Verbose dictionary descriptive term" we can see that results were between 1 and 6 points with average of 4.02 points which corresponds to descriptive term of average abilities.
Analyzing abilities in grammatical structure of language, in variable "Sentences repetition descriptive term" results varied between 3 and 7 points, with average of 4.05 points which corresponds to values of average abilities. In variable "Syntax understanding descriptive term" minimal score was 2 points and maximal score was 6 points with average of 3.98 points, which corresponds to average abilities. In variable "Morphological completion descriptive term" results varied from 3 to 6 points with average of 4.12 points which corresponds to average abilities.

Table 1. Basic statistical indicators of variable that describes linguistic abilities of students of first grades in elementary schools

\begin{tabular}{lccccc}
\hline Variables & N & Min & Max & $\overline{\mathbf{x}}$ & SD \\
\hline DWDT & 165 & 1 & 6 & 5,31 & 1,135 \\
PADT & 165 & 3 & 5 & 4,02 & 0,441 \\
PDT & 165 & 1 & 7 & 4,62 & 0,920 \\
PVDT & 190 & 4 & 7 & 4,55 & 0,655 \\
RVDT & 190 & 1 & 7 & 4,27 & 0,704 \\
VDDT & 190 & 1 & 6 & 4,02 & 0,430 \\
RSDT & 190 & 3 & 7 & 4,05 & 0,402 \\
SUDT & 190 & 2 & 6 & 3,98 & 0,563 \\
MCDT & 190 & 3 & 6 & 4,12 & 0,461 \\
\hline
\end{tabular}

Legend: Differentiation of words descriptive term (DWDT); Phonemic analysis descriptive term (PADT).

Phoneme descriptive term (PDT); Pictorial vocabulary descriptive term (PVDT);Relational vocabulary descriptive term (RVDT); Verbose dictionary descriptive term (VDDT); Repetition of sentences descriptive term (RSDT); Syntax understanding descriptive term (SUDT); Morphological completion descriptive term (MCDT).

In Table 2, results of differences in phonological abilities of the students depending on time spent in kindergarten are shown. Respondents that spent more than three years attending preschool program accomplished better results in variables that describe abilities of differentiat- ing words, phonemic analysis, and phoneme compared to children that attended kindergarten within obligatory program of preschool education with duration of minimal 150 hours during one school year, but that difference did not appear to be statistically significant.

Table 2.Establishing difference in phonological abilities of children depending on time spent in kindergarten

\begin{tabular}{|c|c|c|c|c|c|c|c|}
\hline \multirow[t]{2}{*}{ Variables } & \multicolumn{2}{|c|}{$\underline{\text { Minimal } 150 \text { hours }}$} & \multicolumn{2}{|c|}{ More than 3 years } & \multirow[t]{2}{*}{ df } & \multirow[t]{2}{*}{ t-test } & \multirow[t]{2}{*}{$\mathbf{p}$} \\
\hline & $\overline{\mathbf{X}}_{1}$ & SD $_{1}$ & $\overline{\mathbf{X}}_{2}$ & $\mathbf{S D}_{2}$ & & & \\
\hline DWDT & 5,29 & 1,158 & 5,50 & 0,798 & 163 & $-0,604$ & 0,235 \\
\hline PADT & 4,06 & 0,436 & 4,08 & 0,515 & 163 & $-0,193$ & 0,433 \\
\hline PDT & 4,62 & 0,911 & 4,67 & 1,073 & 163 & $-0,165$ & 0,646 \\
\hline
\end{tabular}

Legend: Differentiation of words descriptive term (DWDT); Phonemic analysis descriptive term (PADT); Phoneme descriptive term (PDT); 
In Table 3 results of differences in semantic abilities of students depending on time spent in kindergarten are shown. Although students that attended organized form of preschool education for more than three years showed better accomplishments in all variables that describe semantic abilities compared to children that only attended obligatory preschool education for 150 hours in one school year, results obtained did not show significant statistical difference in aforementioned abilities.

Table 3. Establishing differences in semantic abilities of children depending on time spent in kindergarten

\begin{tabular}{|c|c|c|c|c|c|c|c|}
\hline \multirow[t]{2}{*}{ Variables } & \multicolumn{2}{|c|}{ Minimal 150 hours } & \multicolumn{2}{|c|}{ More than 3 years } & \multirow[t]{2}{*}{ df } & \multirow[t]{2}{*}{ t-test } & \multirow[t]{2}{*}{$\mathbf{p}$} \\
\hline & $\overline{\mathbf{X}}_{1}$ & SD $_{1}$ & $\overline{\mathbf{X}}_{2}$ & $\mathbf{S D}_{2}$ & & & \\
\hline PDDT & 4,55 & 0,657 & 4,64 & 0,633 & 188 & $-0,535$ & 0,768 \\
\hline RDDT & 4,25 & 0,697 & 4,57 & 0,756 & 188 & $-1,651$ & 0,204 \\
\hline VDDT & 4,01 & 0,542 & 4,43 & 0,646 & 188 & $-1,876$ & 0,065 \\
\hline
\end{tabular}

Legend: Pictorial dictionary descriptive term (PDDT); Relational Dictionary descriptive term (RDDT); Verbose dictionary descriptive term (VDDT)

In Table 4, results of differences in abilities in grammatical structure of language depending on time spent in kindergarten are shown. Statistically significant difference appeared in variable "Morphological completion descriptive term" (t-test $=-3.408$, $\mathrm{p}=0.001)$. Respondents that attended preschool program in duration more than three school years showed statistically better abilities in recognition, understanding and usage of common morphological forms of Bosnian language, compared to children that attended kindergarten within obligatory program of preschool education in duration of minimal 150 hours during one school year. On other variables that describe deviation in grammatical structure of language no significant statistical differences were observed.

Table 4. Establishing differences in abilities in grammatical structure of the language depending on time spent in kindergarten

\begin{tabular}{|c|c|c|c|c|c|c|c|}
\hline \multirow[t]{2}{*}{ Variables } & \multicolumn{2}{|c|}{$\underline{\text { Minimal } 150 \text { hours }}$} & \multicolumn{2}{|c|}{ More than three years } & \multirow[t]{2}{*}{ df } & \multirow[t]{2}{*}{ t-test } & \multirow[t]{2}{*}{$\mathbf{p}$} \\
\hline & $\overline{\mathbf{X}}_{1}$ & SD1 & $\overline{\mathbf{X}}_{2}$ & $\mathbf{S D}_{2}$ & & & \\
\hline RSDT & 4,05 & 0,418 & 4,00 & 0,00 & 188 & 0,457 & 0,068 \\
\hline SUDT & 4,06 & 0,587 & 4,07 & 0,730 & 188 & $-0,540$ & 0,193 \\
\hline MCDT & 4,14 & 0,487 & 4,64 & 0,929 & 188 & $-3,408$ & $0,001 *$ \\
\hline
\end{tabular}

Legend: Repetition of sentences descriptive term (RSDT), Syntax understanding descriptive term (SUDT);Morphological completion descriptive term (MCDT)

\section{DISCUSSION}

Results of this research have shown that students of first grades in elementary schools in variable "Words differentiation descriptive term" have shown excellent abilities. In variables "Phonological analysis descriptive term", "Relational dictionary descriptive term" and "Verbose dictionary descriptive term", obtained results correspond to average abilities. In variables "Phoneme descriptive term" and "Pictorial dictionary descriptive term" obtained results showed average and above average scores. Also, analyzing abilities in grammati- cal structure of language in variables "Repetition of sentences descriptive term", "Syntax understanding descriptive term" and "Morphological completion descriptive term", students scored average results. Author Begic (2009) conducted research in which she wanted, among other things, to examine linguistic abilities on a sample of 64 children, age between 56 and 83 months, where 32 children had disorders in their fluency of speech and other 32 children were in typical linguistic development. 
The author stated that children with no disorders scored excellent average results in variable "Phonological analysis descriptive term", while in variable "Pictorial dictionary descriptive term" children scored outstanding results. In variables "Relational dictionary descriptive term", "Repetition of sentences descriptive term" and "Morphological completion descriptive term, children with no disorders scored excellent results. Comparing results of the author Begic (2009) with our results, we can notice that children with no disorders scored better results in analyzed linguistic variables, than children in our research. Considering that the sample in Begic's research was mostly considering children that attended preschool education, where the research was conducted in the first place, results of her research are in favor of our thesis: attending kindergarten stimulates linguistic development of children. While assessing differences in linguistic abilities of students of first grades in elementary schools depending on duration of attending kindergarten, statistically significant difference appeared in grammatical variable that describes ability of morphological completion, where children who attended kindergarten more than three years showed statistically better results in recognizing, understanding and usage of common morphological forms of Bosnian language compared to children that attended preschool program in duration of minimal 150 hours during one school year. In other variables no statistically significant differences were found. However, we have to point out that respondent who attended kindergarten for more than three years scored better results in almost every variable that describe linguistic abilities, but that difference was not statistically significant. Unfortunately, very little is spoken, written or discussed about importance of preschool education in children's development of sub skills (Cvikić, Jelaska, Kuvač and Novak Milić, 2004). In order to get closer to resolving this problematics, it is important to note that there are two basic but different roles of preschool education and they are taking care of children and addition to upbringing, satisfying educational needs and creating appropriate conditions for development and growth (Kujundžić, 1998, premaCvikić, Jelaska, Kuvač and Novak Milić, 2004). Besides aforementioned important roles of preschool education, it is necessary to point out that material and environmental factors affect children's ability to develop learning capacity. Spatial limitation or lack of environmental stimulations significantly limits number of experiences and impressions that affect children's learning capacity by creating new connections in their brains. Therefore, kindergarten space is not considered only a place where children are when their parents are not around, but a place that has a lot of influence in development of children's intelligence (Camovic, 2011). Based on everything said, we can conclude that for stimulating development abilities of children, adequate human and material resources are needed. On the other hand, Horvat (1986, according to Hasanagic, 2015) presented results of numerous researches and his own, that show that there is no statistically significant correlation between cognitive development and attending kindergarten. Differences in children that attended kindergarten and those who did not are reflected in some other aspects such as higher motivation for achievements, higher activity in school works and desire to be noticed (Zigler and Butterfield, 1968, Levison 1971, Tolicic 1970, according to Hasanagic, 2015). However, Perunovic, Djordjevic and Brkic (1971, according to Hasanagic, 2015), concluded that children that attended kindergarten were more successful in solving numerical problems, they had better graphical expression when writing, they had better motoric condition and were more socially mature in comparison to children that did not attend kindergarten. Hasanagic (2009) explains that children that attended kindergarten show better succress in test of readiness for school in comparison to children that did not attend kindergarten. Aforementioned differences are especially significant in test that measure understanding relations, numerical tests and tests that measure grapho-motoric abilities, which indicates that attending kindergarten stimulates skills development.

\section{CONCLUSION}

Results of this research have shown that, during assessment of differences in linguistic abilities of students of first grade in elementary schools, depending on time spent in kindergarten, there is significant statistical difference in grammatical variable that represents ability of morphological completion, where children that attended kindergarten for three school years or more accomplished statistically better abilities of recognition, understanding and usage of common morphological forms of Bosnian language, compared to children that that attended kindergarten in obligatory preschool program in duration of minimum 150 hours in one school year. In other variables, no statistically significant differences were observed. 
Also, results have shown that respondents that attended three or more years of kindergarten, accomplished better scores in almost all variables that describe linguistic abilities, but no statistically significant differences were found. Attending kindergarten positively affect development of children because many skills and knowledge are stimulated there, both by teachers and peers. Child's development and maturity in different development aspects, including cognition, motorics, social development and linguistic development are very important factors that are connected to enrollment in school. We can say that results of many researches pointed out the positive effects of attending organized forms of preschool education on children's development. Professionals that work on education and rehabilitation of children in development period should educate and stimulate parents to enroll their children in kindergartens in order to stimulate their linguistic development as well as other developing areas of their children.

\section{REFERENCES}

Apel, K., Masterson, J. (2004). Jezik i govor od rođenja do šeste godine. Hrvatska, Lekenik: Ostvarenje.

Baran, J. (2013). Predškolski odgoj i obrazovanje kao socijalna investicija. Studijski centar socijalnog rada.Rev. soc. polit., 20(1): 43-63.

Bartolotta, E.T., Shulman, B.B. (2009).Child development. Preuzeto 20.04.2016. sa http://samples.jbpub. com/9780763747237/47238_CH02_Shulman.pdf.

Begić, L. (2011). Uticaj fonološke i gramatičke kompleksnosti na govorne disfluencije u djece koja mucaju. Doktorska disertacija. Edukacijsko-rehabilitacijski fakultet, Univerzitet u Tuzli.

Brandone, A.C., Salkind, S.J., Golinkoff, R.M., Hirsh-Pasek, K. (2006). Language development. In G. G. Bear \& K. M. Minke (Eds.), Children's needs III: development, prevention, and intervention. USA, Washington D.C.: National Association of School Psychologists: 499-514.
Cvikić, L., Jelaska, Z., Kuvač, J., Novak Milić, J. (2004). Jezičak. Preuzeto 25.04.2016. sa: http://www.cool-school.net/ forum/download.php.

Ćamović, Dž. (2011).Pedagoški poticajno prostorno- materijalno okruženje vrtića- bitna dimenzija dječijeg razvoja i učenja.U: H. Ćurak (Ur.), Kvalitet predškolskog odgoja i obrazovanja u Bosni i Hercegovini.Bosna i Hercegovina, Sarajevo: Agencija za predškolsko, osnovno i srednje obrazovanje: 124- 135. Preuzeto 11.07.2016. sa http://www.aposo.gov.ba/

Federalno Ministarstvo obrazovanja i nauke (2013).Informacija o uključenosti djece predškolskog uzrasta u odgojnoobrazovni proces u godini pred polazak u školu u Federaciji Bosne i Hercegovine. Preuzeto 30.03.2016. sa: http://www.fmon.gov.ba/

Hasanagić, A.(2009).Indikatori zrelosti djece za polazak u školu. Doktorska disertacija. Filozofski fakultet, Univerzitet Istočno Sarajevo.

Hasanagić, A. (2015).Psihološke osnove pripreme djece za školu. Bosna i Hercegovina, Sarajevo: Centar za napredne studije.

Howes,C.,Matheson,C.C., Hamilton, C.E. (1994) Maternal, Teacher, and Child Care History Correlates of Children's Relationships with Peers. Child Development, 1(65): 264- 273.

Ivanovsky, O., Gadasin, I. (2010).Vesela škola s logopedom. Hrvatska, Buševac: Planet Zoe.

Krzewina, J.M. (2012).Effect of Preschool Classroom Quality on Social and Language Development. Theses and Dissertation. University of Wisconsin Milwaukee. Preuzeto 25.05.2016. sa http://dc.uwm.edu/cgi/viewcontent.cgi? article $=1063 \&$ context $=$ etd

Newcomer, P.L., Hammill, D.D. (2008).Test of language development. Texas, Austin: Pro-ed.

Owens, R.E. Jr. (2004).Language disorders. A functional approach to assessment and intervention. USA, State University of New York, Geneseo, New York: Pearson Education, Inc. 